\title{
PENINGKATAN KETERAMPILAN MENULIS SURAT RESMI DENGAN MENGGUNAKAN STRATEGI MENYUSUN KARTU(CARD SORT)
}

\author{
Yustina Neti \\ Guru SMPN I Menjalin \\ Email: yustinanetin@gmail.com
}

\begin{abstract}
This action research aims to describe the planning, implementation and evaluation of learning preparing a formal letter with the strategy card (card sort) in Class VIII B SMP Negeri 1 Establish Year 2011/2012. The method used is descriptive, qualitative research is the shape and type of research is classroom action research. This study using the technique of direct observation and measurement techniques. The results showed that the strategy set the cards (Card sort) managed to improve the ability of students to write a formal letter. In cycle 1 gained an average of 66.70 with a passing grade of $30 \%$, can be classified is still low, at 2 cycles increased by an average of 70.85 with $55 \%$ mastery learning there are students who have not completed the necessary improvements and cycle 3 achieved an average 73.17 and completeness study $85 \%$ said learning has managed in accordance with the expected goals.
\end{abstract}

Keywords : Ability, Write, Strategy Card Sort.

\section{PENDAHULUAN} mencakup empat keterampilan berbahasa, yaitu: menyimak, berbicara, membaca dan menulis. Keempat keterampilan berbahasa ini diharapkan dapat dikuasai oleh anak didik untuk mendorong mereka mencapai prestasi disaat mereka duduk di bangku SMP maupun di luar sekolah.

Berdasarkan kurikulum KTSP (Kurikulum Tingkat Satuan Pendidikan) yang diresmikan tahun 2006, pembelajaran Bahasa Indonesia di tingkat SMP ditekankan pada keempat keterampilan berbahasa. Peserta didik dituntut untuk bisa menguasai keempat keterampilan berbahasa ini. Akan tetapi dalam penerapannya dari keempat keterampilan tersebut hanya keterampilan membaca yang disajikan dalam Ujian Nasional dan keterampilan menulis diujikan dalam ujian sekolah.

Menulis surat merupakan salah satu kemampuan yang diberikan kepada siswa mulai tingkat Sekolah Dasar.Kenyataannya masih banyak siswa yang belum mampu menulis secara benar.

Menulis surat dinas merupakan merupakan pengembangan dari keterampilan menulis. Siswa diharapkan mampu menulis suratdengan baik. Dalam kenyataannya siswa masih banyak belum mampu menulis surat dinas dengan sesuai dengan bentuk surat resmi Indonesia baru menurut Kemendiknas. 
Berdasarkan pengamatan penulis, masih banyak siswa yang masih belum bisa menulis surat resmitersebut. Ada yang belum mengetahui bagaimana sistematika bentuk surat yang benar berdasarkan bentuk surat resmi menurut Kemendiknas.Pada kenyataannya, hanya beberapa siswa yang dapat tuntas dalam pembelajaran menulis surat resmi. Dengan demikian tampaklah bahwa kemampuan menulis surat resmi masih sangat kurang.Hal ini dapat dilihat pada hasil evaluasi belajar siswa.

Pengajaran yang diberikan pada dasarnya bertujuan membantu siswa dalam belajar. Tugas siswa adalah belajar dan guru memfasilitasi dalam proses belajar. Fasilitator dapat diartikan sebagai guru membimbing siswa dalam merespon pernyataan dan membimbing siswa dalam menjawab pertanyaan. Tugas guru juga mendorong siswa untuk berpikir serius dan kreatif dalam menghadapi segala permasalahan belajar.

Kreativitas sangat penting dalam proses belajar mengajar bahasa Indonesia. Siswa akan mendapatkan pengetahuan praktis, khususnya keterampilan menulis surat resmi. Pembelajaran akan tercapai jika ada peran serta siswa dalam proses belajar mengajar, berkaitan dengan pengalaman mereka dan praktek penggunaan bahasa Indonesia dalam kehidupan sehari-hari.

Cara mengatasi masalah yang terjadi dalam proses pembelajaran menulis surat dinas, penulis menggunakan strategi pembelajaran card sort (menyusun kartu). Teknik ini merupakan kegiatan kolaboratif yang bisa digunakan untuk mengajarkan suatu konsep, penggolongan sifat atau mengulangi informasi yang lebih mengutamakan pada gerakan fisik yaitu dengan cara memilih kartu. Selain itu teknik ini bertujuan untuk memberikan peluang kepada siswa untuk dapat berperan lebih aktif dalam pembelajaran serta dapat membantu untuk memberikan energi atau semangat kepada kelas yang telah letih.

Penulis tertarik untuk melakukan penelitian tentang peningkatan keterampilan menulis surat resmi dengan menggunakan strategi card sortpada siswa kelas VIII B SMP Negeri2 Mandor tahun pelajaran 2011/2012. Penelitian ini dilakukan karena penulis ingin menerapkan strategi card sort pada pembelajaran menulis surat. Strategi ini diyakini penulis tepat untuk meningkatkan kemampuan siswa dalam pembelajaran menulis surat resmi.

Berdasarkan latar belakang di atas pembelajaran menulis surat resmi di kelas VIII B SMP Negeri 1 perlu diterapkan strategicard sort. Penulis berasumsi strategi card sort dapat memacu kreativitas siswa sehingga proses pembelajaran menjadi menarik.

Berdasarkan uraian di atas, maka diadakan penelitian tindakan kelas sebagai upaya untuk meningkatkan keterampilan menulis surat resmi. Menurut Silberman (1997:150) strategi menyusun kartu (card Sort) merupakan kegiatan kolaboratif yang bisa digunakan untuk mengajarkan konsep, penggolongan sifat, fakta tentang suatu objek, atau mengulangi informasi. Gerakan fisik yang diutamakan dapat membantu untuk member energy kepada kelas yang 
telah letih. Dengan demikian yang dimaksudkan dengan peningkatan menulis surat resmi adalah bagaimana guru berusaha dalam meningkatkan kompetensinya untuk melakukan perubahan dalam pembelajaran dengan menggunakan srtategi menyusun kartu.

Sesuai dengan perkembangan potensi sumber daya manusia yang diharapkan RPJMN, maka diolah pula sistem pendidikan Nasional dengan menyempurnakan kurikulum yang dikembangkan sesuai dengan hakikat pembelajaran bahasa dan sastra Indonesia. Pengembangan itu bertitik tolak pada bahasa sebagai sarana komunikasi yang mencakup kemampuan berbahasa dan bersastra meliputi aspek mendengar, membaca, berbicara dan menulis.

Kerangka teori yang akan digunakan oleh peneliti dalam penelitian ini meliputi kajian teoritis tentang hakikat belajar, perencanaan pembelajaran, keterampilan menulis, surat, menulis surat resmi Indonesia baru menurut Kemendiknas, strategi pembelajaran card sort.

Anak-anak di sekolah menghadapi situasi pembelajaran yang amat kompleks.Situasi pembelajaran itu kompleks dari sudut pandang mereka dan jauh lebih kompleks lagi dari sudut pandan para psikolog yang dengan gigih berusaha untuk menganalisisnya. Anak-anak mendapatkan pengaruh dari beraneka ragam aspek yang ada di situasi kelas. Mereka belajar banyak hal dari para guru, termasuk hal-hal yang tidak dirumuskan dalam kurikulum dan hal-hal yang tidak disadari oleh guru dan murid itu sendiri (Hill, 2011:2).

Sesuai dengan pengertian belajar mengajar, proses belajar mengajar hendaknya mencerminkan pembangunan pemahaman atau pengetahuan oleh si pembelajar, maka suasana belajar mengajar harus mendorong siswa untuk mengungkapkan pikiran, perasaan dan pengalamannya serta berinteraksi dengan guru dan teman. Untuk itu, guru sebaiknya menciptakan suasana yang membantu pembangunan makna tersebut.

Pengungkapan pikiran sendiri oleh anak sangat baik bagi anak dalam rangka pengembangan potensi diri serta modal guru dalam memahami kondisi si anak. Jadi, seorang guru yang menerapkan pola belajar aktif akan selalu memberikan kesempatan terlebih dahulu kepada anak untuk mengungkapkan pikiran dan perasaan mereka sebelum guru tersebut mengemukakan pendapatnya. Bukankah mengajar itu lebih pada proses mencerdaskan dan bukan memberitahukan. Bila siswa dalam pembelajaran sering diberi tahu dalam dan dalam tes ditagih secara terbatas, maka diperkirakan siswa akan ketergantungan. Siswa tidak mampu berpikir mandiri, berekploitasi, berkreasi, apalagi bersintesa semua serba terbatas.Mereka kurang terlatih berpikir, hanya terlatih mengingat. Akibatnya siswa akan gagap bila berhadapan dengan persoalan baru.

Keterlibatan siswa dalam pembelajaran secara langsung akan memupuk sikap mentalnya dalam bersosialisasi maupun merespon segala hal yang berkaitan dengan keberadaan sebagai anggota kelas. Kondisi ini melahirkan siswa kritis yang mampu berekpresi dan menyampaikan pendapatnya, bahkan menanggapi pendapat orang lain, 
kemudian berusaha menghargai perbedaan antarindividu kelas.

Kegiatan di atas dikembangkan dengan cara mengalami langsung disertai interaksi dengan guru, teman atau teman lainnya.Siswa pada dasarnya memiliki rasa ingin tahu, imajinasi dan fitrah berkeyakinan, bahkan menemukan, untuk dikomunikasikan kepada orang lain. Arikunto dalam Paizaludin dan Ermalinda, 20013:33 meyatakan bahwa penelitian Tindakan Kelas melalui empat tahapan yang lazim yaitu (1) Perencanaan,

Pelaksanaan, (3) Pengamatan dan (4) Refleksi

Dalam tahap ini peneliti menjelaskan tentang apa, mengapa, kapan, di mana, oleh siapa dan bagaimana tidakan tersebut dilakukan. Penelitian tindakan yang ideal sebetulnya dilakukan secara berpasangan antara pihak yang melakukan tindakan dan pihak yang mengamati proses tindakan. Istilah untuk tindakan ini adalah penelitian kolaborasi. Cara ini dikatakan ideal karena adanya upaya untuk mengurangi unsur subjektivitas pengamat serta mutu kecermatan yang dilakukan.

Istilah perencanaan pembelajaran adalah keseluruhan proses analisis kebutuhan dan tujuan belajar serta pengembangan teknik mengajar dan materi pembelajarannya untuk memenuhi kebutuhan tersebut, pengembangan paket pembelajaran, kegiatan mengajar, uji coba, revisi dan kegiatan mengevaluasi hasil belajar. Dengan demikian, perencanaan pembelajaran merupakan proses mempersiapkan seperangkat rencana pelaksanaan pembelajaran guna tercapainya pembelajaran terstruktur. Aspek yang diteliti dalam perencanaan pembelajaran pada penelitian ini adalah silabus yang meliputi semua komponen yang ada di dalamnya.

Tujuan dari perencanaan pembelajaran adalah menguasai sepenuhnya bahan dan materi ajar, metode dan penggunaan alat dan perlengkapan pembelajaran, menyampaikan kurikulum atas dasar bahasan dan mengelola alokasi waktu yang tersedia dan membelajarkan siswa sesuai yang diprogramkan. Sedangkan fungsi perencanaan pembelajaran dapat dijabarkan sebagai berikut:

Menulis merupakan suatu seni dalam menuangkan suatu ide atau gagasam dal satu bentuk tulisan.Sebagai suatu seni, tentunya untuk menulis diperlukan kreativitas. Seorang penulis dituntut untuk bersikap kreatif artinya dapat mengembangkan tulisanya dengan gaya bahasa yang tidak membosankan. Sehingga para pembaca tidak dibuat bosan dan jenuh dengan banyaknya kata-kata yang dituangkan berulang kali (Tedjo, 2006:77)

Menulis adalah kegiatan penyampaian pesan (gagasan, perasaan, atau informasi) secara tertulis kepada pihak lain. Dalam kegiatan berbahasa menulis melibatkan empat unsur, yaitu penulis sebagai penyampai pesan, pesan atau isi tulisan, medium tulisan, serta pembaca sebagai penerima pesan. Kegiatan menulis sebagai sebuah perilaku berbahasa memiliki fungsi dan tujuan: personal, interaksional, informatif, instrumental, heuristik, dan estetis.Menulis ialah menurunkan 
atau melukiskan lambang-lambang grafik yang menggambarkan suatu bahasa yang dipahami oleh seseorang, sehingga orang-orang lain dapat dapat membaca lambanglambang tersebut kalau mereka memahami bahasa dan gambaran grafik itu. Gambaran atau lukisan mungkin dapat menyampaikan makna-makna, tetapi tidak menggambarkan kesatuan-kesatuan bahasa. Menulis merupakan representasi bagian dari kesatuankesatuan ekspresi bahasa. Hal ini merupakan perbedaan utama antara lukisan dan tulisan, antara meluis dan menulis. Melukis gambar bukanlah menuls. Seorang pelukis dapat saja melukis huruf-huruf cina, tetapi dia tidak dapat dikatakan menulis, kalau dia tidak tahu bahaimana cara menulis bahasa Cina, yaitu kalau dia tidak memahami bahasa Cina beserta huruf-hurufnya. Dengan kriteria seperti itu, dapatlah dikatakan bahwa menyalin/mengkopi huruf-huruf ataupun menyusun menset suatu naskah dalam huruf-huruf tertentu untuk dicetak bukanlah menulis kalau orang-orang tersebut tidak memahami bahasa terebut beserta representasinya. Demikian Lado dalam (Tarigan,2008:22).

Sebagai satu di antara aspek dari keterampilan berbahasa, menulis atau mengarang merupakan kegiatan yang kompleks. Kompleksitas menulis terletak pada tuntutan kemampuan untuk menata dan mengorganisasikan ide secara runtut dan logis, serta menyajikannya dalam ragam bahasa tulis dan kaidah penulisan lainnya. Akan tetapi, di balik kerumitannya, menulis menjanjikan manfaat yang begitu besar dalam membantu pengembangan daya inisiatif dan kreativitas, kepercayaan diri dan keberanian, serta kebiasaan dan kemampuan dalam menemukan, mengumpulkan, mengolah, dan menata informasi. Surat adalah alat untuk menyampaikan suatu maksud secara tertulis (Finoza, 1991:3). Menurut Kamus Besar Bahasa Indonesia KBBI 1995:978 surat dinas adalah surat yang dikirim oleh pemerintah.

Surat dapat merupakan bukti "hitam di atas putih", lagi pula surat dapat menyimpan rahasia dan biaya pembuatan dan pengirimannya relatif murah. Orang juga menganggap surat sebagai urusan atau duta organisasi atau instansi dari pengirim surat. Surat dipandang sebagai citra, cermin mentalitas, jiwa, serta suatu petunjuk kondisi intern organisasi yang bersangutan (Wiyasa, 1996:2).

Surat adalah informasi tertulis yang dapat dipergunakan sebagai alat komunikasi tulis yang dibuat dengan persyaratan tertentu yang khusus berlaku untuk surat menyurat (Finoza,1991:4). Bahasa Surat yang dimaksud dengan bahasa yang jelas dalam bahasa surat adalah kejelasan bahasa menyangkut pemahaman suatu maksud. Bila maksud seorang penulis dipahami oleh pembaca secara utuh dengan penafsiaran tunggal, berarti bahasanya jelas. Apabila maksud penulis tidak dimengerti oleh pembaca atau dimengerti namun penafsirannya ganda, berarti bahasanya tidak jelas. Ketidakjelasan dapat disebabkan oleh banyak faktor mulai dari kesalahan ejaan sampai ketidakrapian penataan alinea.

Bahasa yang lugas dapat diartikan sederhana, bersahaja, 
langsung pada permasalahan. Dalam dunia bisnis orang menginginkan segala sesuatu serba cepat dan serba praktis. Makna itulah yang dihimpun ke dalam satu kata, yaitu lugas.

\section{METODE}

Penelitian ini akan dilaksanakan SMP Negeri 2 Mandor kelas VIII B dengan subjek penelitian adalah siswa kelas VIII B yang berjumlah 40 siswa, yang terdiri dari siswa perempuan 22 siswa laki-laki 18.

Metode yang digunakan dalam penelitian ini adalah metode deskriptif yaitu suatu cara pemecahan masalah untuk menggambarkan sesuatu yang berkenaan dengan kondisi atau kejadian yang sedang berlangsung saat dilaksanakannya penelitian ini digunakan oleh peneliti untuk menggambarkan keadaan objek penelitian, yaitu siswa kelas VIII B SMP Negeri 2 Mandor.

Penelitian ini berbentuk penelitian kualitatif yang akan menghasilkan data deskriptif berupa kata-kata tertulis dan prilaku yang diamati. Perilaku yang diamati adalah kemampuan siswa dalam menyusun dan menulis surat resmi sesuai dengan sistematika surat resmi yang benar.

Penelitian tindakan kelas bertujuan untuk memperbaiki praktisi secara langsung, di tempat itu dan saat itu juga Raka Joni dalam (Agung, 2012:70). Penelitian ini membahas pra pembelajaran dan tindak lanjut setelah pembelajaran. Pada pra pembelajaran penulis melakukan pengamatan dalam mengajar sehingga dapat menemukan kekurangan dan kelemahan dalam pembelajaran menulis surat resmi.
Pada tahap tindak lanjut penulis memecahkan masalah tentang pembelajaran menulis surat resmi. pelajaran Bahasa Indonesia dan siswa kelas VIII B SMP Negeri 2 Mandorberjumlah 40 orang yang terdiri dari siswa perempuan 22 dan siswa laki-laki 18.Peneliti berkolaborasi dengan guru mata pelajaran Bahasa Indonesia, yaitu Maria Rina, S.Pd sebagai pengamat.

Data dalam penelitian ini sebagai adalah daftar nilai menulis surat resmi dengan strategi card sort Maret-Mei 2012.Proses pembelajaran dan penulisan surat resmi oleh siswa.

Teknik Pengumpulan Data a) Observasi Langsung, suatu teknik untuk mengumpulkan data tentang strategi card sort yang digunakan guru dalam pembelajaran menulis surat resmi dan juga dilaksanakan observasi terhadap siswa. b) Tenik Komunikasi Lansung, peneliti melakukan wawancara dengan guru dan siswa untuk melengkapi data yang diinginkan.Wawancara dilakukan berpedoman pada daftar pertnyaan yang telah tersedia. c) Teknik Studi Dokumenter, suatu bentuk kegiatan penelaahan dokumentasi berupa buku-buku pedoman yang sesuai dengan masalah penelitian dan perangkat pembelajaran.

Instrumen dalam penelitian ini, yaitu: a) silabus dan kisipembelajaran, b) rencana pelaksanaan pembelajaran c) pedoman penilaian berdasarkan indikator dengan skor yang sudah ditentukan. d) pedoman observasi, yaitu alat yang digunakan peneliti untuk mengamati kegiatan pembelajaran menulis surat resmi dengan strategi card sort, dengan memberikan tanda centang pada 
lembar observasi. e) pedoman wawancara, yaitu alat pengumpul data yang telah disusun. Pedoman ini berisi pertanyaan-pertanyaan tentang hal yang berhubungan dengan penggunaan strategi card sort pada pembelajaran menulis surat resmi.

Dalam penelitian ini analisis data dilakukan dengan menggunakan teknik deskriptif kualitatif, yaitu untuk menggambarkan persentase dan rata-rata variabel berikut: a) data berupa hasil pengamatan, dianalisis dengan menggunakan deskriptif kualitatif, b) data hasil belajar dianalisis dengan membandingkan nilai tes, c) data yang diperoleh dari hasil observasi pada setiap siklus dijadikan bahan refleksi.

\section{HASIL DAN PEMBAHASAN Hasil}

Penelitian untuk meningkatkan kemampuan menulis surat resmi dengan menggunakan strategi card sortdi VIII B SMP Negeri 2 Mandor tahun pelajaran 2011/2012. Penelitian ini difokuskan di kelas VIII B dengan jumlah siswa 40 orang yang terdiri dari 22 siswa perempuan dan 18 siswa laki-laki.

Berdasarkan hasil prapenelitian tanggal 2 April 2012 menyatakan bahwa nilai rata-rata menulis surat resmi siswa kelas VIII B SMP Negeri 2 Mandor tahun pelajaran 2011/2011 adalah 60,51 dan tidak memenuhi Kriteria Ketuntasan Minimum (KKM) yang telah ditentukan yaitu 70. Kesulitan yang dialami siswa yaitu penguasaan EYD, pilihan kata/diksi dan menulis surat sesuai dengan sistematika surat yang benar. Kondisi yang demikian disebabkan karena siswa-siswi tidak dibekali pengetahuan yang memadai tentang sistematika penulisan surat yang benar dalam pembelajaran sebelumnya.

Siklus pertama dilaksanakan ada hari Jumat tanggal 20 April 2012. Sebelum membuat perencanaan, peneliti berdiskusi dengan guru bidang studi dan kepala sekolah mengenai pembelajaran yang akan diterapkan di kelas VIII B yaitu strategi card sord, setelah sepakat dan memiliki pemahaman yang sama mengenai strategi card sort, peneliti dan guru bersama-sama membuat rencana pembelajaran sesuai dengan langkah-langkah pembelajaran strategi card sort.Semua instrumen yang akan digunakan dalam penelitian dipersiapkan secara matang, agar tindakan yang dilakukan dapat terlaksana dan terarah sesuai dengan perencanaan yang telah dibuat. Perencanaan disini memiliki peran yang sangat penting dalam keberhasilan sebuah program, dalam hal ini keberhasilan dalam menerapkan perencanaan menulis suratdengan strategi card sort. Perncanaan pembelajaran pada siklus I akan mengemukakan jadwal kegiatan, silabus dan Rencana Pelaksanaan Pembelajaran (RPP) menulis surat resmi dengan strategi card sort.

Perencanaan siklus II dilaksanakan pada hari Rabu, 2 Mei 2012. Setelah melihat hasil pada siklus I, peneliti dan kolaborator membuat rencana pembelajaran beserta peringkat yang menerapkan strategi card sort yang berbeda pada proses pembelajaran pada siklus I. Dengan demikian siswa mulai termotivasi dalam proses pembelajaran. Guru menjelaskan kembali sistematika dan penggunaan 
bahasa baku dalam surat resmi siswa diminta satu persatu kedepan kelas menyusun potongan-potongan kertas surat resmi pada kertas karton yang ditempel pada papan tulis, dan siswasiswa yang lain memperhatikan, guru juga menyiapkan pedoman-pedoman observasi yang akan digunakan peneliti dalam mengamati kegiatan pembelajaran yang dilakukan oleh guru dan siswa melalui strategi card sort. Semua instrumen yang akan digunakan dalam penelitian dipersiapkan secara matang, agar tindakan yang dilakukan dapat terlaksana dan terarah sesuai dengan perencanaan yang telah dibuat. Perencanaan di sini memliki peran yang sangat penting dalam keberhasilan sebuah program, dalam hal ini keberhasilan menerapkan pembelajaran menulis surat resmi dengan strategi card sort.

Perencanaan siklus III dilaksanakan pada hari Senin,14 Mei 2012.Setelah melihat hasil siklus II, peneliti dan guru membuat rencana pembelajaran beserta perangkatnya yang menerapkan strategi card sort yang berbeda dengan proses pembelajaran pada siklus I dan siklus II. Guru menjelaskan kembali sistematika surat resmi dan penggunaan bahasa baku dalam surat resmi. Siswa dibagi dalam kelompok yang terdiri dari 2 orang, siswa diminta menyusun potonganpotongan surat resmi pada kertas tipis yang telah disediakan. Semua instrumen yang akan digunakan dalam penelitian dipersiapkan secara matang, agar tindakan yang akan dilakukan dapat terlaksana dan terarah sesuai dengan perencanaan yang telah dibuat. Perencanaan disini memiliki peran yang sangat penting dalam keberhasilan sebuah program, dalam hal ini keberhasilan dalam menerapkan pembelajaran menulis surat resmidengan strategi card sort.

Pelaksanaan pembelajaran menulis surat resmi dengan strategicard sort dilakukan melalui 3 siklus. Ketiga siklus pelaksanaan pembelajaran tersebut akan dibahas pada pembahasan bab ini. Pelaksanaan pembelajaran dapat dipilah berdasarkan tindakan, pengamatan dan refleksi. Ketiga hal tersebut merupakan kajian dari sebuah pelaksanaan pembelajaran agar sesuai dengan perencanaan yang telah dibuat sebelumnya. Sebelum melakukan tindakan perlu diketahui bahwa kemampuan siswa dalam menulis surat resmi. Sebelum dilakukan tindakan masih sangat rendah. Nilai yang diperoleh $(65,20)$ dan siswa yang mencapai tingkat ketuntasan hanya $(30 \%)$ atau 15 siswa (lihat tabel). Penelitian ini dilakukan secara kolaborasi dengan rekan sejawat penulis dan sesama guru bahasa Indonesia yaitu Maria Rina.

Rata-rata hasil menulis surat resmi pada siklus I adalah 66,70 . Nilai belum memenuhi kriteria ketuntasan minimum (KKM) yaitu 70.Siswa yang tuntas sebesar $30 \%$, sedangkan yang belum tuntas $70 \%$.Rendahnya nilai siswa pada siklus I disebabkan karena sebagian besar siswa belum memahami sistematika surat resmi. Penguasaan EYD dan pilihan kata/diksi pada bahasa surat juga masih rendah.

Penilaian siklus ke II hasil refleksi siklus I, rata-rata hasil menulis surat resmi pada siklus II adalah 70,85. Siswa yang sudah tuntas sebesar 55\%, sedangkan siswa 
yang belum tuntas sebesar 45 $\%$.Sesuai dengan kriteria ketuntasan minimum yaitu 70 .Sudah mulai ada peningkatan dari siklus I.

Penilaian siklus ke III hasil refleksi siklus II, rata-rata hasil menulis surat resmi pada siklus II adalah 73,17. Siswa yang sudah tuntas sebesar $85 \%$, sedangkan siswa yang belum tuntas sebesar $15 \%$. Sesuai dengan kriteria ketuntasan minimum yaitu 70 .Siswa sudah dapat menulis surat resmi dengan baik.

\section{Pembahasan}

Berdasarkan hasil penelitian tindakan kelas yang dilakukan dapat dihasilkan beberapa hal sebagai berikut: 1) Perencanaan pembelajaran menulis surat resmi dengan menggunakan card sort secara umum dapat dilakukan dengan baik pada setiap siklus. Penyusunan program dapat didahului dengan menyusun program tahunan, program semester, silabus dan Rencana Pelaksanaan Pembelajaran (RPP). Pada siklus I,II dan III hanya dikemukakan penyusunan jadwal kegiatan, silabus dan RPP yang berhubungan dengan kegiatan menulis surat resmi. Penyusunan silabus dan RPP menulis surat resmi diawali dengan analisis aspek standar kompetensi, kompetensi dasar, tujuan pembelajaran, materi ajar, metode pembelajaran, skenario pembelajaran, sumber-sumber belajar, penilaian proses dan hasil belajar. Siklus I dilaksanakan pada hari Jumat, 20 April 2012, siklus II dilaksanakan hari Rabu, 2 Mei 2012 dan siklus III dilaksanakan ada hari Senin, 14 Mei 2013. Sebelum melakukan rancangan sebuah perencanaan, peneliti sebagai guru menentukan strategi card sort yang akan diterapkan dalam pembelajaran menulis surat resmi. Beberapa persiapanyang dilakukan oleh peneliti pada setiap siklus diantaranya: (a) pembuatan RPP, (b) menyiapkan pedoman observasi terlaksana atau tidaknya penerapan pembelajaran menulis surat resmi dengan strategi card sort, (c) pedoman observasi sikap siswa dalam mengikuti pembelajaran menulis surat resmi. 2) Pelaksanaan pembelajaran menulis surat resmi dengan menggunakan strategi card sort. Tindakan pembelajaran dilakukan melalui 3 siklus, siklus I dilaksanakan pada hari Senin, 23 April 2012, siklus II ilaksanakan pada hari Senin, 7 Mei 2012 dan siklus III dilaksanakan pada hari Rabu, 16 Mei 2012. Tindakan setiap siklus selalu menggunakan tahap-tahap sebagai berikut: a) guru membuka tanya jawab, b) menjelaskan tujuan pembelajaran, c) siswa mengidentifikasi dan mencermati contoh surat resmi Indonesia baru menurut Kemendiknas, d) guru membagi siswa dalam kelompok, dalam satu kelompok terdiri dari 2 orang, e) guru membagikan potongan-potongan kertas surat resmi yang sudah diacak, f) siswa diminta menyusun potongan-potongan surat resmi yang sudah diacak pada kertas HVS yang disediakan, g) setiap siswa diminta menulis surat resmi berkenaan dengan kegiatan sekolah dengan sistematika dan format yang tepat serta bahasa yang baku, h) siswa dan guru melakukan refleksi dan akhirnya menutup pembelajaran.

Pelaksanaan pembelajaran juga menghasilkan sikap atau respon siswa mengenai pemeblajaran. Respon siswa kelas VIII B SMP Negeri 2 
Mandor tahun pelajaran 2011/2012 dalam mengikuti pembelajaran menulis surat resmi dengan strategi cardsort menunjukkan sikap antusias dan termotivasi.

Hasil pembelajaran surat resmi dengan menggunakan strategi card sort. Rata-rata hasil menulis surat resmi dengan strategi card sortsiswa kelas VIII B SMP Negeri 2 Mandor tahun pelajaran 2011/2012 mengalami peningkatan yaitu siklus I 66,70 (30\%), siklus II 70,85 (55\%) dan siklus III 73,17 (85\%).

Tabel 1

Ketuntasan Belajar Siswa Secara Klasikal

\begin{tabular}{llccccc}
\hline No & Keterangan & \multirow{2}{*}{$\begin{array}{c}\text { Jumlah } \\
\text { Siswa }\end{array}$} & $\mathbf{0 - 6 9}$ & $\mathbf{7 0 - 1 0 0}$ & $\begin{array}{c}\text { Rata- } \\
\text { rata } \\
\text { Kelas }\end{array}$ & $\begin{array}{c}\text { Ketuntasan } \\
\text { Belajar }\end{array}$ \\
\hline 1 & Siklus I & 40 & 28 Siswa & 12 Siswa & 66,70 & $30 \%$ \\
\hline 2 & Siklus II & 40 & 18 Siswa & 22 siswa & 70,85 & $55 \%$ \\
\hline 3 & Siklus III & 40 & 6 siswa & 34 siswa & 73,17 & $85 \%$ \\
\hline
\end{tabular}

\section{KESIMPULAN DAN SARAN}

\section{Kesimpulan}

Berdasarkan hasil penelitian tindakan kelas yang dilakukan dapat disimpulkan pelaksanaan pembelajaran juga menghasilkan sikap atau respon yang baik dari siswa mengenai pemebelajaran menulis surat resmi. Respon siswa kelas VIII B SMP Negeri 2 Mandor tahun pelajaran 2011/2012 dalam mengikuti pembelajaran menulis surat resmi dengan strategi cardsort menunjukkan sikap antusias dan termotivasi. Hasil pembelajaran surat resmi dengan menggunakan strategi card sort. Rata-rata hasil menulis surat resmi dengan strategi card sortsiswa kelas VIII B SMP Negeri 2 Mandor tahun pelajaran 2011/2012 mengalami peningkatan yaitu siklus I 66,70 (30\%), siklus II 70,85 (55\%) dan siklus III $73,17(85 \%)$.

\section{DAFTAR RUJUKAN}

Agung,I. 2012. Panduan Penelitian Tindakan Kelas Bagi Guru. Jakarta: Bestari Buana Murni.

\section{Saran}

Berdasarkan hasil penelitian ini, penulis ingin menyarankan beberapa hal terkait dengan pembelajaran menulis surat resmi dengan strategi card sort. 1) Siswa hendaknya belajar lebih giat lagi, supaya nilai yang diperoleh menjadi lebih baik.2)Guru sebaiknya selalu kreatif dan inovatif dalam menentukan strategi pembelajaran, gunakanlah strategi card sort untuk materi pembelajaran surat resmi. Strategi card sort ini diyakini mampu memacu kreativitas dan daya tarik siswa dalam pembelajaran, khususnya menulis surat resmi.3)Kepala sekolah diharapkan selalu memberikan dukungan dan fasilitas kepada guru maupun siswa dalam proses pembelajaran.

Uno, HB. 2010. Model Pembelajaran yang Menciptakan Proses Belajar Mengajar yang 
Kreatif dan Efektif. Jakarta: Bumi Aksara.

Depdikbud. 1995. Kamus Besar Bahasa Indonesia Edisi Kedua. Jakarta: Balai Pustaka. Endang, S, Mulyani S dan Suyeti. 2009. Modul Melakukan Prosedur Administrasi untuk SMK dan MAK.Jakarta: Erlangga.

Finoza, L. 1991. Aneka Surat Sekretaris dan Bisnis Indonesia. Jakarta: Usaha Mulia.

Paizaludin dan Ermalinda. 2013. Penelitian TindakanKelas PanduanTeoritis dan Praktis. Bandung: Alfabeta.

Pratama, ZA. 2000. Teknik menulis Surat Menyurat Lengkap. Yogyakarta: Bintang Cemerlang.
Sanjaya, W. 2006. Strategi pembelajaran Berorientasi Estándar Proses pendidikan. Jakarta: Prenada.

Silberman, M. 2007.Active Learning. Yogyakarta: Yappendis.

Tarigan, HG. 1982. Menulis Sebagai Suatu Keterampilan Berbahasa. Bandung: Angkasa.

Tedjo,T. 2006. Menulis Seni Mengungkapkan Hati. Bandung: Agape.

Hill, W. 2011.Theories of Learning. Bandung: Nusa Media.

Wiyasa, T. 1996. Pola Dasar Penyusunan Surat-Surat Resmi. Jakarta: Pradya Paramita. 